\title{
Challenges and science-based implications for modern management and conservation of European ungulate populations
}

\author{
Marco Apollonio $^{1}$ • Vladimir V. Belkin ${ }^{2} \cdot$ Jakub Borkowski $^{3}$ • Oleg I. Borodin ${ }^{4} \cdot$ Tomasz Borowik $^{5}$. \\ Francesca Cagnacci ${ }^{6} \cdot$ Aleksey A. Danilkin $^{7}$ • Peter I. Danilov ${ }^{2}$ Andrey Faybich ${ }^{8}$. Francesco Ferretti ${ }^{9}$. \\ Jean Michel Gaillard ${ }^{10}$ - Matt Hayward ${ }^{11}$ - Pavel Heshtaut ${ }^{8}$. Marco Heurich ${ }^{12,13}$ • Aliaxandr Hurynovich ${ }^{8}$.

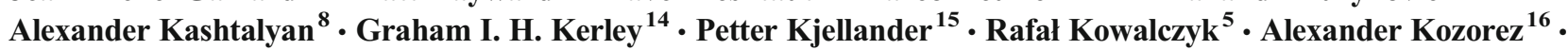 \\ Sergey Matveytchuk ${ }^{17}$. Jos M. Milner ${ }^{18}$ • Atle Mysterud ${ }^{19}$ • Jānis Ozoliņš ${ }^{20}$ • Danila V. Panchenko ${ }^{2}$. \\ Wibke Peters $^{19}$ - Tomasz Podgórski ${ }^{5}$ - Boštjan Pokorny ${ }^{21,22}$ • Christer Moe Rolandsen ${ }^{23} \cdot$ Vesa Ruusila $^{24}$. $^{2}$ \\ Krzysztof Schmidt $^{5}$ (D) Taras P. Sipko ${ }^{7} \cdot$ Rauno Veeroja $^{25} \cdot$ Pavel Velihurau $^{4} \cdot$ Gregoriy Yanuta $^{4}$
}

Received: 6 February 2017 / Accepted: 25 May 2017 /Published online: 7 June 2017

(C) The Author(s) 2017. This article is an open access publication

\begin{abstract}
Wildlife management systems face growing challenges to cope with increasingly complex interactions between wildlife populations, the environment and human activities. In this position statement, we address the most important issues characterising current ungulate conservation and management in Europe. We present some key points arising from ecological research
\end{abstract}

Communicated by: Dries Kuijper

Krzysztof Schmidt

kschmidt@ibs.bialowieza.pl

1 University of Sassari, Sassari, Italy

2 Institute of Biology of Karelian Research Centre, Russian Academy of Sciences, Petrozavodsk, Russia

3 University of Warmia and Mazury, Olsztyn, Poland

4 Scientific and Practical Center, National Academy of Sciences of Belarus for Biological Resources, Minsk, Belarus

5 Mammal Research Institute, Polish Academy of Sciences, Białowieża, Poland

6 Fondazione Edmund Mach, Trento, Italy

7 A.N. Severtsov Institute of Ecology and Evolution, Moscow, Russia

8 Scientific and Practical Centre for Wildlife Resources Management "Krasny Bor", Dabrapliosy, Belarus

9 University of Siena, Siena, Italy

10 Claude Bernard University Lyon 1, Lyon, France

11 Bangor University, Bangor, UK that may be critical for a reassessment of ungulate management in the future.

Keywords Ecosystem · Population sustainability · Science-based management $\cdot$ Wildlife management $\cdot$ Adaptive management
13 Wildlife Ecology and Management, University of Freiburg, Freiburg, Germany

14 Nelson Mandela University, Port Elisabeth, South Africa

15 Swedish University of Agricultural Sciences, Riddarhyttan, Sweden

16 Department of Game Management, Belarussian State Technological University, Minsk, Belarus

17 Federal Research Institute of Game Management and Fur Farming, Kirov, Russia

18 University of Aberdeen, Aberdeen, UK

19 University of Oslo, Oslo, Norway

20 State Forest Research Institute "Silava”, Salaspils, Latvia

21 Environmental Protection College, Velenje, Slovenia

22 Slovenian Forestry Institute, Ljubljana, Slovenia

23 Norwegian Institute for Nature Research, Trondheim, Norway

24 Natural Resources Institute of Finland, Helsinki, Finland

25 Estonian Environment Agency, Tartu, Estonia 
Wildlife management systems face growing challenges to cope with the increasingly multifaceted interactions between wildlife populations, the environment and human activities. Dense ungulate populations, such as those occurring in many parts of Europe, have impacts on agriculture and forestry production. In addition, landscape fragmentation, due to the development of infrastructure, is leading to an increase in ungulate-traffic collisions and the synurbization of many species, while a few species and subspecies are still endangered (Apollonio et al. 2010). Simultaneously, populations of large carnivores - the ungulates' natural limiting factor-are returning and stabilising in some areas of Europe (Chapron et al. 2014).

In such a context, ungulates should not be managed in isolation, but as important "ecosystem engineers" (Smit and Putman 2011) and to do so means that they need to be considered as an integral part of both ecosystems and ecosystem management. It is thus necessary to develop a holistic approach that enables the widespread presence of ungulates to be considered as an opportunity and a renewable resource rather than a nuisance, and to manage ungulate species and populations in the face of a changing environment and human society.

In this position statement, we address some of the most important issues characterising current ungulate management and conservation in Europe. We present some key points arising from ecological research that may be critical for a reassessment of ungulate management in the future and highlight some of the knowledge gaps. The goal of this statement is to provide wildlife managers and policymakers with a modern perspective of the position of ungulates in the ecosystem. We believe it should be used to support the redirection of current management plans and goals to ensure the viability and endurance of sustainable ungulate populations. We propose ten management and conservation measures to help achieve this.

\section{The role of ungulates in forest ecosystems}

The impacts of ungulate herbivory on forest vegetation are crucial for shaping the age and species composition and spatial structure of forests. This includes the formation of open areas, which play an important role in maintaining the heterogeneity of habitats required to support a diversity of fauna and flora, as well as impacts on tree regeneration (Kuijper 2011; Clasen et al. 2015). The maintenance of sustainable wild, native ungulate populations is thus an important mechanism in both the conservation and restoration of forest ecosystems. However, many interacting factors affect forest composition besides browsing, and successful germination, survival and growth of seedlings are also influenced by seed predation, competition within and between tree species and weather conditions (Kuijper et al. 2010; Nopp-Mayr et al. 2012, Cailleret et al. 2014, Leonardsson et al. 2015). Effective and scientifically sound management of well-integrated ungulate-forest ecosystems should be based on inferences from welldesigned research and monitoring. These should include the long-term assessment of ecosystem effects across the full spectrum of ungulate densities and environmental productivity. Such knowledge could be used to develop indices and indicators to evaluate and predict browsing effects across a range of temporal and spatial scales.

\section{Multi-ungulate communities and competition}

A trend towards restoring or creating more complex multiungulate communities has been occurring in many regions of Europe over recent decades (Apollonio et al. 2010). Natural processes such as the expansion of native ungulate species are involved, as well as translocation of non-native ones (Dolman and Wäber 2008; Ferretti and Lovari 2014). This has markedly increased the number of locally coexisting species in some communities (Bartoš et al. 2002). Ecological theory predicts that as interspecific competition increases, species increasingly specialize on the resources they use most efficiently (Namgail et al. 2009; Anderwald et al. 2016). Consequently, an overlap of diet and realized ecological niches between species may foster niche contraction, leading to a decline in population density and fitness of less competitive species (Forsyth and Hickling 1998; Ferretti et al. 2015). Interactions between herbivores, including feeding behaviour, dietary plasticity and diet selectivity, therefore need to be studied to generate reliable predictions of the grazing and browsing pressures in multi-ungulate ecosystems. Such information is also important in understanding the influences of alien ungulate species on native taxa, as well as promoting sustainable game use and the conservation of biological diversity.

Interspecific competition can amplify negative effects of environmental changes on important aspects of foraging and social behaviour of native ungulates (Mason et al. 2014). These in turn may decrease their reproductive performance and offspring survival, which are major determinants of population trends. Moreover, environmental changes may also amplify (or release) the potential for competition between native species. Therefore, extreme care should be taken when (re)introductions of ungulates are planned, particularly within the geographic range of threatened taxa (Lovari et al. 2014). Given the potential of non-native species to out-compete native ones, the introduction of non-native ungulates should be avoided.

\section{Large carnivores, human hunting and disturbance}

Ungulates show close relationships with predators, which shape their population dynamics and affect their evolutionary ecology (Jędrzejewska and Jędrzejewski 2005). These 
relationships may be particularly influenced by climatic anomalies and limiting ecological conditions (Wilmers et al. 2007; Melis et al. 2009). Predators are known to exert both direct (density mediated) and indirect (risk mediated) effects on prey (Creel and Christianson 2008). The risks associated with predators' presence affect ecosystems through trophic, scale-dependent interactions (trophic cascades), emphasizing inseparable links between predators, herbivores and vegetation (Kuijper et al. 2013; Ripple et al. 2014, 2016). Prey species have evolved behavioural and physiological adaptations to the risks associated with predators (Creel et al. 2007; Boonstra 2013; Kuijper et al. 2014; Wikenros et al. 2015). Herbivores may respond to predation risk by shifting foraging sites. This can create spatial variation in grazing and browsing pressure, with the potential to influence vegetation composition and dynamics (Creel et al. 2005; Hernández and Laundré 2005). On the other hand, human activities contribute to a broad spectrum of disturbances that may also affect ungulates both directly and indirectly (Hayward et al. 2015; Lone et al. 2015). In the case of hunting, which represents by far the most important mortality cause of wild ungulates in Europe, the risk experienced by animals varies depending on season and hunting method (Grignolio et al. 2011; Cromsigt et al. 2013). Therefore, human-induced risks may differ from and even exceed those of natural predators.

Populations of ungulates under natural predation pressure in concert with a hunting harvest may decline, as most ungulates (with the notable exception of wild boar) cannot compensate for such additive mortality by increased fecundity or reduced age at first reproduction (Vucetich et al. 2005). This problem is more pronounced at high latitudes, where productivity is low (Melis et al. 2009) and will lead to reduced predator carrying capacity (Hayward et al. 2007). Therefore, the link between natural predation, human hunting, ungulate responses and ecosystem effects should be closely assessed in wildlife and habitat management systems, to ensure the longterm viability and persistence of both ungulates and their predators (Jędrzejewski et al. 2011).

\section{Population dynamics}

Climatic changes can contribute to the decline of some ungulates, especially of arctic or alpine species (Vors and Boyce 2009) and those at the southern limit of their distributional ranges (Grayson and Delpech 2005), while others benefit from warming and are expanding their ranges northwards (Elmhagen et al. 2015; Vetter et al. 2015). Management systems therefore need to account for possible mismatches between population phenology, life histories and changing resource availability. This is particularly true for thermally sensitive species that cannot cope with high temperatures (van Beest and Milner 2013).
Individual variation in animal-habitat relationships is increasingly appreciated. Individual characteristics in terms of their behavioural phenotype (i.e. animal personality) may influence juvenile survival, natal dispersal and the resource acquisition-risk avoidance trade-off (Bonnot et al. 2015). Because these individual differences have important repercussions for population dynamics, they also have potential knock-on effects on population management.

\section{Migrations}

Migration is an adaptation to seasonal variation in limiting resources and is commonly assumed to positively affect reproductive performance of migrants (Rolandsen et al. 2017). Many ungulate populations are partially migratory, which means that only a proportion of the population migrates, while the remainder stays resident on the same range year-round (Cagnacci et al. 2011; Mysterud et al. 2011). Migration is likely triggered by forage maturation in spring (Bischof et al. 2012) and is related to snow fall and the onset of the hunting season in autumn (Rivrud et al. 2016).

Recently, a decrease in the migration rate of several species has been observed (Harris et al. 2009; Cole et al. 2015). Climate change, anthropogenic pressure and possibly changes in predator-prey dynamics have all been indicated as potential drivers of this decline. The loss of migratory behaviour in ungulates could have significant consequences for the ecosystems encompassed by their seasonal ranges and affect population dynamics. Impairment of migration (e.g. by anthropogenic landscape effects) could contribute to population declines. Migration behaviour differs among populations within species in relation to individual traits and environmental factors (Cagnacci et al. 2011). The plasticity in migration patterns needs to be considered in population management. Furthermore, because a large fraction of populations may cross administrative boundaries during migration, appropriate management practices should be implemented across large geographic scales to reflect migratory processes. A new approach to ungulate management should be developed that accounts for the dynamic and variable character of migration (either to maintain migration or adapt to the change of movement patterns).

\section{Supplementary feeding}

Supplementary feeding can enhance survival, reproduction and population growth under adverse conditions (Milner et al. 2014; Putman and Staines 2004). However, there is limited evidence of the effectiveness of diversionary feeding to protect crops, forest regeneration and natural habitats, with any positive effects often being undermined by increases in 
ungulate density. The feeding of wild ungulates often has unintended effects, which are typically complex (Milner et al. 2014). These may involve changes to vegetation composition and structure with consequent cascading effects on other trophic levels (Mathisen and Skarpe 2011), as well as exacerbating within- and between-species disease persistence and transmission risks (Sorensen et al. 2014), browsing damage and competition between ungulate species (Felton et al. 2017). We urge managers to consider both the costs and benefits of supplementary and diversionary feeding before deciding whether to feed ungulates or not.

\section{Genetic composition of ungulates}

Various management practices (selective harvesting, translocation, captive-breeding, fencing, introduction of non-native species) lead to changes in the gene pool of ungulates within populations (Randi 2005; Linnell and Zachos 2011; Niedziałkowska et al. 2012; Fernández-García et al. 2014). Consequences of such changes may include a decline in genetic variability, an increase in inbreeding, a decrease in population viability and the loss of local adaptations (Zachos et al. 2007; Zachos and Hartl 2011; Galarza et al. 2015). There is an urgent need for research to quantify these risks and identify solutions, as well as to develop policies and regulations to manage these emerging threats. Genotyping methods could be implemented as valuable tools to monitor genetic changes in ungulate populations, maintenance of their original genetic structure and to perform more precise censuses, particularly in the case of rare or endangered species (Giglio et al. 2016).

\section{Ungulate management databases}

An important goal of a vision for European ungulate management is to increase the scientific basis of wildlife management, rather than to rely only on opinion/experience-based management systems. To achieve this, consistent long-term monitoring and systematically collected data are essential. Tools for the remote capture, digital storing and processing of largescale data related to ungulate management (e.g. observations, harvest, mortality and recruitment rates) have become available and are commonly used in several European countries (Ueno et al. 2014; Zaragozí et al. 2015; Helle et al. 2016; Bubnicki et al. 2016). As accurate spatial data accumulates, it will provide valuable information for e.g. preventing forest or agricultural damage and/or implementing mitigation measures to reduce ungulate-traffic collisions. In addition to ensuring effective and adaptive management, remotely accessible spatial databases are an important asset for scientific research concerning the interactions of ungulates with the environment and human activities, both within countries and at a
pan-European scale. Therefore, the engagement of hunters in game research and field work or as contributors of databases should be encouraged. Such initiatives should be promoted across national borders to develop a pan-European approach to ungulate management.

\section{Hunting and disease management}

It has become increasingly apparent that hunting has wider ranging effects than solely reducing densities of ungulates (Setsaas et al. 2007; Mysterud 2014; Festa-Bianchet 2017). Selective removal of individuals may change aspects of social organization and dispersal rates (Milner et al. 2007; Allendorf and Hard 2009; Averbeck et al. 2010; Borg et al. 2015, Leclerc et al. 2017), while hunting disturbance can induce escape movements and temporary home range displacement (Kamei et al. 2010; Grignolio et al. 2011; Thurfjell et al. 2013; Jarnemo and Wikenros 2014). In the case of wild boar, repeated hunting disturbance may affect social structure, leading to an increase in fission-fusion dynamics in the population, potentially facilitating the spread of diseases (Iacolina et al. 2009; Scillitani et al. 2010; Saïd et al. 2012). To reduce the risk of diseases spreading into and between ungulate populations, it may be beneficial to minimize hunting disturbance in disease-prone areas. For example, less intensive hunting methods such as single hunts do not cause long-distance movements of animals, leading to lower disturbance than drive hunts. However, the suitability of hunting methods must also be judged in the light of their efficiency to manage ungulate density, and in many cases, driven hunts may be a more effective way to achieve this goal.

\section{Conservation of endangered species: the European bison as a model}

Particular attention should be paid to the conservation and management of endangered ungulates. The iconic European bison plays a flagship role in nature conservation and rewilding programmes in several countries of Europe and serves as a powerful model for the conservation of other European ungulates (Kerley et al. 2012; van de Vlasakker 2014). Effective conservation of the bison requires a refining of conservation targets and the development of sound sciencebased management, built on strong partnerships between scientists and managers. Conservation should counteract actual and potential threats to the bison and result in the wider restoration of the species. One of the first steps in a new approach to bison management should be the identification of suitable habitats and a reduction of human intervention (specifically supplementary feeding and culling). Large-scale farm abandonment in Eastern Europe creates favourable opportunities 
for bison restoration in optimal, open habitats (Kerley et al. 2012). However, reintroductions of bison to post-Soviet countries also require improved protection regimes to avoid uncontrolled hunting and poaching.

\section{Proposed management and conservation measures to ensure the viability and long-term persistence of sustainable ungulate populations}

1. Effective management of ungulates should not be undertaken in isolation from the ecosystem. Long-term research and monitoring of performance indicators of habitat productivity and ecosystem responses are required across the full gradient of ungulate densities.

2. Re-establishment of native ungulate populations should be considered as an important component of the conservation and restoration of ecosystems. However, great caution should be undertaken when translocation, captive-breeding and fencing are considered as elements of the ungulate management system. Measures to avoid hybridization between species and subspecies should be implemented, and the introduction of non-native ungulate species should be avoided.

3. Knowledge of foraging selectivity and interactions between herbivores should be applied to optimise feeding pressure in ecosystems where the manipulation of species composition and densities is used as a management tool. This should enhance conservation of biological diversity and efficiency of game use.

4. Close attention should be paid to the link between predation and ungulate responses, both in wildlife and habitat management. Consideration of the variable effects of predation in wildlife management is crucial to ensure long-term viability and persistence of both ungulates and predators. As human harvesting effects may differ from those of predators, human hunting should not automatically be considered as an adequate substitute.

5. The timing of life history events (phenology) and its individual variability, as well as changes in resource availability due to climate and anthropogenic changes, need to be considered in ungulate management systems.

6. Plasticity in migration patterns should be considered in management strategies. A new approach to ungulate management should be developed to account for the dynamic and variable characteristics of migration, either to maintain migration or to adapt to changes in movement patterns. Ideally, population management units should reflect the annual spatial requirements of the different species.

7. Supplementary and diversionary feeding can have complex, indirect and unintended effects. Therefore, careful analysis of disease and conservation risks, as well as economic issues, should be taken into account when considering feeding. Many feeding programmes should be reviewed accordingly.

8. Citizen science is a powerful source of data for wildlife management. Online, remotely accessible databases with spatial and temporal information on ungulate harvests, distribution and abundances should be developed and implemented to provide data on interactions of ungulates with the environment and human activities at national and pan-European scales. Data persistence, standardization and accessibility (including linguistic accessibility) should be promoted.

9. Wildlife management should recognise the impacts of hunting beyond simply reducing population densities. Hunting may lead to changes in both behaviour and social organization of ungulates and affect movements over short and long distances. These could potentially play important roles in the transmission of parasites and diseases. Management practices that cause disturbance and increase contact rates within and between populations and/or species should therefore be considered in the light of the risk of infectious disease transmission.

10. The effective management and conservation of ungulates (particularly endangered species) requires a redefinition of goals and the development of strong partnerships between scientists, managers and conservationists to ensure science-based management strategies are established. Identification and protection of suitable habitats, designation of "wildlife migration corridors", control of poaching, "re-naturalization" of populations, understanding and preventing the risks of inbreeding and disease transmission, and accounting for climate change are all formidable challenges for ungulate management that warrant joint efforts beyond national borders.

\section{Critical issues for the management of ungulates in Belarus and other post-Soviet countries with similar management models}

Management of ungulates as a renewable resource would benefit from being based on the achievements of modern ecological science. In Belarus, as well as in some other countries of the former Soviet Union, the approaches and principles, upon which management is based, have remained unchanged for the past 50 years.

Currently, ungulate management in Belarus is based on two indices:

1. A static assessment of "optimal population size" of a given species in a particular area, determined by habitat quality estimated from vegetation surveys. 
2. Population size, obtained by conducting censuses.

The achievements of modern ecology together with examples of successful adaptive management of wildlife populations in some European countries allow us to conclude that these principles are based on outdated theories due to the following:

1. Each terrestrial ecosystem provides resources and living conditions for many animal species. It is, however, not possible to reliably determine the desired ungulate population size by assessing habitat quality using vegetation surveys alone.

Habitat quality and carrying capacity are dynamic entities with no scientifically justified or comprehensive method of evaluation. Evaluation attempts based on vegetation abundance and species composition should be linked to the knowledge of population performance to become more reliable and hence should only serve as testable hypotheses (Van Horne 1983; Hobbs and Hanley 1990; Hall et al. 1997; Johnson 2007).

2. Despite the existence of a large number of direct and indirect census methods for ungulates, their reliability and accuracy are often unknown and most likely low. Ungulates are notoriously difficult to count (Morellet et al. 2007; Bonefant et al. 2009).

3. Most census methods are based not on direct animal counts, but rather on abundance indices (such as dung counts or number of animal tracks on a transect), which are then transformed into estimates of animal numbers. Due to the unknown relationship between abundance indices and true population size, abundance indices should not be directly converted to population densities or numbers. Indices may provide a useful indicator of whether a population is increasing, decreasing or stable within a given area, but should nonetheless be used with caution because of their high reliance on detection probability which is variable. The use of abundance indices should be preceded by extensive replication and validation against independent measures of population density (Anderson 2001; Anderson 2003; Witmer 2005).

In order to improve the management of ungulate populations, we propose implementing an adaptive management approach instead of relying upon the existing model. Adaptive management corresponds to an organized and systematic trial-and-error (learning by doing) process and was offered by the international scientific community in the face of uncertainty and constant variability of factors affecting wildlife populations. Adaptive management explicitly defines our understanding of ecological systems as a hypothesis, and management interventions can be seen as tests of predictions arising from this hypothesis. Adaptive management requires that the outcomes of interventions are monitored with a set of population (e.g. body mass, antler quality, jaw length, reproduction performance, health status of individuals) and environmental (e.g. browsing index, vegetation composition, damages in agriculture) indices, which are used to continually revise the hypothesis. Based on this, explicit management aims should be formulated prior to any action (e.g. changing population size) in relation to ethical or economic considerations (Lancia et al. 1996).

We welcome the accession of the Republic of Belarus to the "Convention on the Conservation of European Wildlife and Natural Habitats" in 2013. We also encourage all countries that have not yet implemented the "European Charter for Hunting and Biodiversity" adopted by the Standing Committee of the Convention in 2007 to do so. The charter recommends and provides the legal basis for implementing the principles of adaptive management practices in the management of wildlife resources.

Acknowledgements The position statement presented in this article has been undertaken by participants of the International Conference "Ungulates in a changing world - consequences for population dynamics, migration and management", 19-21 September 2016, Krasny Bor, Belarus. We are grateful to two anonymous reviewers for comments that have helped to substantially enrich the statement.

Open Access This article is distributed under the terms of the Creative Commons Attribution 4.0 International License (http:// creativecommons.org/licenses/by/4.0/), which permits unrestricted use, distribution, and reproduction in any medium, provided you give appropriate credit to the original author(s) and the source, provide a link to the Creative Commons license, and indicate if changes were made.

\section{References}

Allendorf FW, Hard JJ (2009) Human-induced evolution caused by unnatural selection through harvest of wild animals. PNAS 106(Supplement 1):9987-9994

Anderson DR (2001) The need to get the basics right in wildlife field studies. Wildlife Soc B 29:1294-1297

Anderson DR (2003) Response to Engeman: index values rarely constitute reliable information. Wildlife Soc B 31:288-291

Anderwald P, Haller RM, Filli F (2016) Heterogeneity in primary productivity influences competitive interactions between red deer and alpine chamois. PLoS One 11(1):e0146458

Apollonio M, Andersen R, Putman R (2010) European ungulates and their management in the $21^{\text {st }}$ century. Cambridge University Press, Cambridge

Averbeck C, Apio A, Plath M, Wronski T (2010) Hunting differentially affects mixed-sex and bachelor-herds in a gregarious ungulate, the impala (Aepyceros melampus: Bovidae). Afr J Ecol 48:255-264

Bartoš L, Vanková D, Miller KV (2002) Interspecific competition between white-tailed, fallow, red, and roe deer. J Wildl Manag 66: $522-527$ 
Bischof R, Loe LE, Meisingset E, Zimmermann B, Van Moorter B, Mysterud A (2012) A migratory northern ungulate in the pursuit of spring: jumping or surfing the green wave? Am Nat 180:407-424

Bonefant C, Gaillard J-M, Coulson T, Festa-Bianchet M, Loison M, Garel M, Loe LE, Blanchard P, Pettorelli N, Owen-Smith N, Du Toit J, Duncan P (2009) Empirical evidence of density dependence in populations of large herbivores. Adv Ecol res 41:317-318

Bonnot N, Verheyden H, Blanchard P, Cote J, Debeffe L, Cargnelutti B, Klein F, Hewison AJM, Morellet N (2015) Interindividual variability in habitat use: evidence for a risk management syndrome in roe deer? Behav Ecol 26:105-114

Boonstra R (2013) Reality as the leading cause of stress: rethinking the impact of chronic stress in nature. Funct Ecol 2:11-23

Borg BL, Brainerd SM, Meier TJ, Prugh LR (2015) Impacts of breeder loss on social structure, reproduction and population growth in a social canid. J Anim Ecol 84:177-187

Bubnicki JW, Churski M, Kuijper DPJ (2016) TRAPPER: an open source web-based application to manage camera trapping projects. Methods Ecol Evol 7:1209-1216

Cagnacci F, Focardi S, Heurich M, Stache A, Hewison AJM, Morellet N, Kjellander P, Linnell JDC, Mysterud A, Neteler M, Delucchi L, Ossi F, Urbano F (2011) Partial migration in roe deer: migratory and resident tactics are end points of a behavioural gradient determined by ecological factors. Oikos 120:1790-1802

Cailleret M, Heurich M, Bugmann H (2014) Reduction in browsing intensity may not compensate climate change effects on tree species composition in the Bavarian Forest National Park. Forest Ecol Manag 328:179-192

Chapron G, Kaczensky P, Linnell JD, von Arx M, Huber D, Andrén H, López-Bao JV, Adamec M, Álvares F, Anders O et al (2014) Recovery of large carnivores in Europe's modern humandominated landscapes. Science 346:517-1519

Clasen C, Heurich M, Glaesener L, Kennel E, Knoke T (2015) What factors affect the survival of tree saplings under browsing, and how can a loss of admixed tree species be forecast? Ecol Model 305:1-9

Cole EK, Foley AM, Warren JM, Smith BL, Dewey SR, Brimeyer DG, Fairbanks WS, Sawyer H, Cross PC (2015) Changing migratory patterns in the Jackson elk herd. J Wildlife Manage 79:877-886

Creel S, Christianson D (2008) Relationships between direct predation and risk effects. Trends Ecol Evol 23:194-201

Creel S, Christianson D, Liley S, Winnie JA (2007) Predation risk affects reproductive physiology and demography of elk. Science 315:960

Creel S, Winnie J, Maxwell B, Hamlin K, Creel M (2005) Elk alter habitat selection as an antipredator response to wolves. Ecology 86:33873397

Cromsigt JPGM, Kuijper DPJ, Adam M, Beschta RL, Churski M, Eycott A, Kerley GIH, Mysterud A, Schmidt K, West K (2013) Hunting for fear: innovating management of human-wildlife conflicts. J Appl Ecol 50(3):544-549

Dolman PM, Wäber K (2008) Ecosystem and competition impacts of introduced deer. Wildlife Res 35:202-214

Elmhagen B, Kindberg J, Hellström P, Angerbjörn A (2015) A boreal invasion in response to climate change? Range shifts and community effects in the borderland between forest and tundra. Ambio 44(Suppl 1):39-50

Felton AM, Felton A, Cromsigt JPGM, Edenius L, Malmsten J, Wam HK (2017) Interactions between ungulates, forests, and supplementary feeding: the role of nutritional balancing in determining outcomes. Mamm Res 62:1-7

Fernández-García JL, Carranza J, Martínez JG, Randi E (2014) Mitochondrial D-loop phylogeny signals two native Iberian red deer (Cervus elaphus) lineages genetically different to western and eastern European red deer and infers human-mediated translocations. Biodivers Conserv 23:537-554
Ferretti F, Corazza M, Campana I, Pietrocini V, Brunetti C, Scornavacca D, Lovari S (2015) Competition between wild herbivores: reintroduced red deer and Apennine chamois. Behav Ecol 26:550-559

Ferretti F, Lovari S (2014) Introducing aliens: problems associated with invasive exotics. In: Putman R, Apollonio M (eds) Behaviour and management of European ungulates. Whittles Publishing, Dunbeath, pp 78-109

Festa-Bianchet M (2017) When does selective hunting select, how can we tell, and what should we do about it? Mam rev 47:76-81

Forsyth DM, Hickling GJ (1998) Increasing Himalayan tahr and decreasing chamois densities in the eastern Southern Alps, New Zealand: evidence for interspecific competition. Oecologia 113:377-382

Galarza JA, Sanchez-Fernandez B, Fandos P, Soriguer R (2015) The genetic landscape of the Iberian red deer (Cervus elaphus hispanicus) after 30 years of big-game hunting in southern Spain. J Wildlife Manage 79:500-504

Giglio RM, Ivy JA, Jones LC, Latch EK (2016) Evaluation of alternative management strategies for maintenance of genetic variation in wildlife populations. Anim Conserv 19:380-390

Grayson DK, Delpech F (2005) Pleistocene reindeer and global warming. Conserv Biol 19:557-562

Grignolio S, Merli E, Bongi P, Ciuti S, Apollonio M (2011) Effects of hunting with hounds on a non-target species living on the edge of a protected area. Biol Conserv 144:641-649

Hall LS, Krausman PR, Morrison ML (1997) The habitat concept and a plea for standard terminology. Wildlife Soc B 25:173-182

Harris G, Thirgood S, Hopcraft JGC, Cromsigt JPGM, Berger J (2009) Global decline in aggregated migrations of large terrestrial mammals. Endang Species Res 7:55-76

Hayward MW, O'Brien J, Kerley GIH (2007) Carrying capacity of large African predators: predictions and tests. Biol Conserv 139:219-229

Hayward MW, Ortmann S, Kowalczyk R (2015) Risk perception by endangered European bison Bison bonasus is context (condition) dependent. Landsc Ecol 30:2079-2093

Helle P, Ikonen K, Kantola A (2016) Wildlife monitoring in Finland: online information for game administration, hunters, and the wider public. Can J For Res 46:1491-1496

Hernández L, Laundré JW (2005) Foraging in the 'landscape of fear' and its implications for habitat use and diet quality of elk Cervus elaphus and bison Bison bison. Wildlife Biol 11:215-220

Hobbs NT, Hanley TA (1990) Habitat valuation: do use/availability data reflect carrying capacity? J Wildlife Manage 54:515-522

Iacolina L, Scandura M, Bongi P, Apollonio M (2009) Nonkin association in wild boar social units. J Mammal 90:666-667

Jarnemo A, Wikenros C (2014) Movement pattern of red deer during drive hunts in Sweden. Eur J Wildl res 60:77-84

Jędrzejewska B, Jędrzejewski W (2005) Large carnivores and ungulates in European temperate forest ecosystems: bottom-up and top-down control. In: Ray JC, Redford KH, Steneck RS, Berger J (eds) Large carnivores and the conservation of biodiversity. Island Press, Washington - Covelo - London, pp 230-246

Jędrzejewski W, Apollonio M, Jędrzejewska B, Kojola I (2011) Ungulate-large carnivores relationships in Europe. In: Putman R, Apollonio M, Andersen R (eds) Ungulate management in Europe - problems and practices. Cambridge University Press, Cambridge, pp 284-318

Johnson MD (2007) Measuring habitat quality: a review. Condor 109: 489-504

Kamei T, Takeda K, Izumiyama S, Ohshima K (2010) The effect of hunting on the behavior and habitat utilization of sika deer (Cervus nippon). Mamm Study 35:235-241

Kerley GIH, Kowalczyk R, Cromsigt JPGM (2012) Conservation implications of the refugee species concept and the European bison: king of the forest or refugee in a marginal habitat? Ecography 35:519529 
Kuijper DPJ (2011) Lack of natural control mechanisms increases wildlife-forestry conflict in managed temperate European forest systems. Eur J For Res 130:895-909

Kuijper DPJ, Cromsigt JPGM, Jędrzejewska B, Miścicki S, Churski M, Jędrzejewski M, Kweczlich I (2010) Bottom-up versus top-down control of tree regeneration in the Białowieża Primeval Forest, Poland. J Ecol 98:888-899

Kuijper DPJ, de Kleine C, Churski M, van Hooft P, Bubnicki J, Jedrzejewska B (2013) Landscape of fear in Europe: wolves affect spatial patterns of ungulate browsing in Białowieża Primeval Forest, Poland. Ecography 36:1263-1275

Kuijper DPJ, Verwijmeren M, Churski M, Zbyryt A, Schmidt K, Jędrzejewska B, Smit C (2014) What cues do ungulates use to assess predation risk in dense temperate forests? PLoS One 9:e84607

Lancia R, Braun C, Collopy M, Dueser R, Kie J, Martinka C, Nichols JD, Nudds TD, Porath WR, Tilghman N (1996) ARM! For the future: adaptive resource management in the wildlife profession. Wildlife Soc B 24:436-442

Leclerc M, Frank SC, Zedrosser A, Swenson JE, Pelletier F (2017) Hunting promotes spatial reorganization and sexually selected infanticide. Sci Rep 7:45222

Leonardsson J, Löf M, Götmark F (2015) Exclosures can favour natural regeneration of oak after conservation-oriented thinning in mixed forests in Sweden: a 10-year study. Forest Ecol Manag 354:1-9

Linnell JDC, Zachos F (2011) Status and distribution patterns of European ungulates: genetics, population history and conservation. In: Putman R, Apollonio M, Andersen R (eds) Ungulate management in Europe - problems and practices. Cambridge University Press, Cambridge, pp 12-53

Lone K, Loe LE, Meisingset EL, Stamnes I, Mysterud A (2015) An adaptive behavioral response to hunting: surviving male red deer shift habitat at the onset of the hunting season. Anim Behav 102: $127-138$

Lovari S, Ferretti F, Corazza M, Minder I, Troiani N, Ferrari C, Saddi A (2014) Unexpected consequences of reintroductions: competition between reintroduced red deer and Apennine chamois. Anim Conserv 17:359-370

Mason THE, Stephens PA, Apollonio M, Willis SG (2014) Predicting potential responses to future climate in an alpine ungulate: interspecific interactions exceed climate effects. Glob Change Biol 20: 3872-3882

Mathisen KM, Skarpe C (2011) Cascading effects of moose (Alces alces) management on birds. Ecol res 26:563-574

Melis C, Jędrzejewska B, Apollonio M, Bartoń KA, Jędrzejewski W, Linnell JDC, Kojola I, Kusak J, Adamic M, Ciuti S, Delehan I, Dykyy I, Krapinec K, Mattioli L, Sagaydak A, Samchuk N, Schmidt K, Shkvyrya M, Sidorovich VE, Zawadzka B, Zhyla S (2009) Predation has a greater impact in less productive environments: variation in roe deer, Capreolus capreolus, population density across Europe. Glob Ecol Biogeogr 18:724-734

Milner JM, Nilsen EB, Andreassen HP (2007) Demographic side effects of selective hunting in ungulates and carnivores. Conserv Biol 21: $36-47$

Milner JM, Van Beest FM, Schmidt KT, Brook RK, Storaas T (2014) To feed or not to feed? Evidence of the intended and unintended effects of feeding wild ungulates. J Wildlife Manage 78:1322-1334

Morellet N, Gaillard J-M, Hewison AJM, Ballon P, Boscardin Y, Duncan P, Klein F, Maillard D (2007) Indicators of ecological change. New tools for managing populations of large herbivores. J Appl Ecol 44: 634-643

Mysterud A (2014) Effects of selective harvesting on ungulate populations. In: Putman R, Apollonio M (eds) Behaviour and management of European ungulates. Whittles Publishing, Dunbeath, pp 124-147

Mysterud A, Loe LE, Zimmermann B, Bischof R, Veiberg V, Meisingset E (2011) Partial migration in expanding red deer populations at northern latitudes - a role for density dependence? Oikos 120: $1817-1825$

Namgail T, Mishra C, de Jong CB, van Wieren SE, Prins HHT (2009) Effects of herbivore species richness on the niche dynamics and distribution of blue sheep in the Trans-Himalaya. Divers Distrib 15:940-947

Niedziałkowska M, Jędrzejewska B, Wójcik JM, Goodman SJ (2012) Genetic structure of red deer population in northeastern Poland in relation to the history of human interventions. J Wildlife Manage 76: 1264-1276

Nopp-Mayr U, Kempter I, Muralt G, Gratzer G (2012) Seed survival on experimental dishes in a central European old-growth mixed-species forest - effects of predator guilds, tree masting and small mammal population dynamics. Oikos 121:337-346

Putman RJ, Staines BW (2004) Supplementary winter feeding of wild red deer Cervus elaphus in Europe and North America: justifications, feeding practice and effectiveness. Mammal Rev 34:285-306

Randi E (2005) Management of wild ungulate populations in Italy: captive-breeding, hybridisation and genetic consequences of translocations. Vet Res Commun 29(Suppl 2):71-75

Ripple WJ, Estes JA, Beschta RL, Wilmers CC, Ritchie EG, Hebblewhite M, Berger J, Elmhagen B, Letnic M, Nelson MP, Schmitz OJ, Smith DW, Wallach AD, Wirsing AJ (2014) Status and ecological effects of the world's large carnivores. Science 343:1241484

Ripple WJ, Estes JA, Schmitz OJ, Constant V, Kaylor MJ, Lenz A, Motley JL, Self KE, Taylor DS, Wolf C (2016) What is a trophic cascade? Trends Ecol Evol 31:842-849

Rivrud IM, Bischof R, Meisingset EL, Zimmermann B, Loe LE, Mysterud A (2016) Leave before it's too late: anthropogenic and environmental triggers of autumn migration in a hunted ungulate population. Ecology 97:1058-1068

Rolandsen CM, Solberg EJ, Sæther B-E, Moorter BV, Herfindal I, Bjørneraas K (2017) On fitness and partial migration in a large herbivore - migratory moose have higher reproductive performance than residents. Oikos 126:547-555

Saïd S, Tolon V, Brandt S, Baubet E (2012) Sex effect on habitat selection in response to hunting disturbance: the study of wild boar. Eur J Wildlife Res 58:107-115

Scillitani L, Monaco A, Toso S (2010) Do intensive drive hunts affect wild boar (Sus scrofa) spatial behaviour in Italy? Some evidences and management implications. Eur J Wildlife Res 56:307-318

Setsaas TH, Holmern T, Mwakalebe G, Stokke S, Røskaft E (2007) How does human exploitation affect impala populations in protected and partially protected areas?-a case study from the Serengeti Ecosystem, Tanzania. Biol Conserv 136:563-570

Smit C, Putman R (2011) Large herbivores as 'environmental engineers'. In: Putman R, Apollonio M, Andersen R (eds) Ungulate management in Europe - problems and practices. Cambridge University Press, Cambridge, pp 260-284

Sorensen A, van Beest FM, Brook RK (2014) Impacts of wildlife baiting and supplemental feeding on infectious disease transmission risk: a synthesis of knowledge. Prev Vet Med 113:356-363

Thurfjell H, Spong G, Ericsson G (2013) Effects of hunting on wild boar Sus scrofa behaviour. Wildlife Biol 19:87-93

Ueno M, Solberg EJ, Iijima H, Rolandsen CM, Gangsei LE (2014) Performance of hunting statistics as spatiotemporal density indices of moose (Alces alces) in Norway. Ecosphere 5(2):13

van de Vlasakker J (2014) Rewilding Europe Bison Rewilding Plan, 2014-2024. Publication by Rewilding Europe, Nijmegen

Van Beest FM, Milner JM (2013) Behavioural responses to thermal conditions affect seasonal mass change in a heat-sensitive northern ungulate. PLoS One 8:e65972

Van Horne B (1983) Density as a misleading indicator of habitat quality. J Wildlife Manage 47:893-901 
Vetter SG, Ruf T, Bieber C, Arnold W (2015) What is a mild winter? Regional differences in within-species responses to climate change. PLoS One 10(7): 0132178

Vors LS, Boyce MS (2009) Global declines of caribou and reindeer. Glob Chang Biol 15:2626-2633

Vucetich JA, Smith DW, Stahler DR (2005) Influence of harvest, climate and wolf predation on Yellowstone elk, 1961-2004. Oikos 111:259270

Wikenros C, Kuijper DPJ, Behnke R, Schmidt K (2015) Behavioural responses of ungulates to indirect cues of an ambush predator. Behaviour 152:1019-1040

Wilmers CC, Post E, Hastings A (2007) The anatomy of predator-prey dynamics in a changing climate. J Anim Ecol 76:1037-1044
Witmer GW (2005) Wildlife population monitoring: some practical considerations. Wildlife res 32:259-263

Zachos FE, Althoff C, von Steynitz Y, Eckert I, Hartl GB (2007) Genetic analysis of an isolated red deer (Cervus elaphus) population showing signs of inbreeding depression. European J Wild res 53:61-67

Zachos FE, Hartl GB (2011) Phylogeography, population genetics and conservation of the European red deer Cervus elaphus. Mammal rev 41:138-150

Zaragozí B, Belda A, Giménez P, Navarro JT, Bonet A (2015) Advances in camera trap data management tools: towards collaborative development and integration with GIS. Ecol Inform 30:6-11 